\title{
Impact of Coal-Fired Thermal Power Plant on Pulmonary Health of Primary School Children
}

\author{
Purushottam Pramanik ${ }^{1}$, Indranarayan Ganguli ${ }^{2}$, Sanchita Rakshit ${ }^{3}$, \\ Rohitaswa Chowdhury ${ }^{4}$ \\ ${ }^{1}$ Government General Degree College, Singur, Hooghly, West Bengal And \\ ${ }^{2,3,4}$ Post Graduate Department of Physiology, Hooghly Mohsin College, Chinsurah, Hooghly, \\ West Bengal, India
}

\begin{abstract}
Demand for electricity generation increasing gradually with the advancing of civilization. InIndia $75 \%$ of the total power obtained is from coal-based thermal power plant. In India ash content in the coal used for power generation is 30-40\%.Thus power generation from coal results in emission of a variety of pollutants including fly ash. Annually 65 million tons of fly ash is generated as waste product in India and causes serious air pollution. Children are more susceptible to it. Therefore this study was planned to assess the pulmonary health status of primary school children aged 6-9 years living in the vicinity of thermal power plant. Subjects were divided into two groups: control (living within $5 \mathrm{~km}$ radius from power plant) and control (living more than $25 \mathrm{~km}$ away from power plant) group. Anthropometric parameters such as height and weight were measured and body mass index and body surface area were derived. The lung function parameters studied were FVC, FEV1, PEFR, FIVC, FIV1, PIF, FEF25-75\% and mid vital capacity. Pulmonary function test indicates that living within vicinity of a coal-fired thermal power plant can result in significant reduction of all pulmonary function indices. Percentagedecrease of inspiratory parameters (FIVC, FIV1, FIF50 and PIF) was more than expiratory parameters. PEF and PIF which are more dependent upon air ways are very much reduced, because the effects of the pollutants are more on bronchial tree. Ratio of mid vital capacity was comparatively higher than control counterpart which indicates variable type extra thoracic air way obstruction. Spirometric findings suggest that living within vicinity of a coal-fired thermal power plant can result in obstructive lung disease both in extrathorasic and bronchial tree. So children reside within the vicinity of coal-fired thermal power plant should undergo immediate lung function test to detect their pulmonary health status so that proper preventing measures or treatment is possible
\end{abstract}

Keywords: Spirometry, thermal power plant, asthma, respiratory health, coal, children

\section{Introduction}

The demand of electricity generation increases gradually with the ever- increasing growth of human civilization. Throughout the world thermal power plants are major contributors of electricity. Coal-fired thermal power plants generate $41 \%$ of world electricity (1). Coal-based thermal power plants have been a major source of power generation in India, where $75 \%$ of total power obtained is from coal-based thermal power plants (2). In India ash content in the coal used for power generation is 30-40\%. High ash coal means more wear and tear of the plant and machinery, low thermal efficiency of the boiler, slogging and choking of the furnace and most serious one is generation of large amount of fly ash. India stand on fourth position in the world for the production of coal fly ash as by-product waste. After the combustion of coalin boiler $20 \%$ of the ash collected at the bottom called bottom ash remaining $80 \%$ is carried along with the Coal fumes. A 500MW thermal power plant releases 200metric tons $\mathrm{SO}_{2}, 70$ tons $\mathrm{NO}_{2}$ and 500 tone fly ash approximately every day. Particulate matter (PM) constitutes the fly ash. PM may be deposited into any of the three respiratory compartments: the extra thoracic, tracheobronchial and alveolar regions (3). PM>10 $\mu \mathrm{m}$ diameter (super coarse particle) is deposited in the extra thoracic region, PM with a diameter between 5 and $10 \mu \mathrm{m}$ (coarse particles) is deposited in the tracheobronchial region and particles $<2.5 \mu \mathrm{m}$ in diameter (fine particles) are deposited in the alveolar region (4).The submicron particles enter deeper into lungs and are deposited on the alveolar walls where the metals transferred to the blood across the cell membrane. All the heavy metal (atomic number below 92) of fly ash is toxic in nature. The source and composition of particles determine their toxicity $(5,6)$, but size is a major factor determining toxicity in the lungs due to the generation of reactive oxygen and nitrogen species. In general particles exacerbate acute and pre-existing respiratory diseases including viral infection, asthma, bronchitis and chronic respiratory disease $(7,8)$. Asthma exacerbation has been linked specifically to exposure to ozone $\left(\mathrm{O}_{3}\right)$, a gas produced when $\mathrm{NO}_{2}$ reacts with volatile organic compounds in presence of sunlight and heat $(9)$. $\mathrm{NO}_{2}$ and very small particles, known as PM2.5 adversely affect lung development and reduction of forced expiratory volume (FEV) among children (10). A $10 \mu \mathrm{g} / \mathrm{m}^{3}$ increase in $\mathrm{PM}_{2.5}$ is associated with a $1 \%$ to $3.4 \%$ decrease in 
FEV1, a measure of lung function, in asthmatic children (11). In addition to respiratory illness, long term exposure to $\mathrm{PM}_{2.5}$ is causally linked to the development of lung cancer (6). When asthmatic children are exposed to $\mathrm{NO}_{2}$ they can experience increase in wheezing and cough (12). $\mathrm{NO}_{2}$ exposure at high concentration (1-2 ppm) causes airway inflammation and low concentration $(0.2-0.5 \mathrm{ppm})$ causes decrement in lung function in asthmatics (12). Exposure to $\mathrm{SO}_{2}$ emitted by coal burning power plants causes inflammation and hyper responsiveness of the airways aggravates bronchitis, and decrease lung function (13).

Children are particularly susceptible to air pollutants because they breathe more air in respect to their body weight, spend additional time outside, remain active outdoors during midday when air pollution levels tend to be higher and they inhale more air per unit body weight than adults. Because of their smaller stature their breathing zone is also smaller, so they inhale air loaded with more particles. It may also be due to the immaturity of their enzyme and immune systems, which assist in detoxifying pollutants, combined with incomplete pulmonary development (14). These factors appear to act in concert to make children highly susceptible to airborne pollutants such as those emitted by coal-fired power plants (15).

Thus this study was carried out in order to detect the effects of coal-fired thermal power plants'emission on pulmonary health status of school children having age limit 6-9 years

\section{Material And Methods}

Area of the study:The Kolaghat thermal power plant $\left(22^{\circ} 24^{\prime} 56^{\prime \prime} \mathrm{N} 87^{\circ} 52^{\prime} 12^{\prime \prime} \mathrm{E}\right)$ is situated on the right bank of the Rupnarayan river at Mecheda in the PurbaMedinipur district of West Bengal State. It is located approximately $55 \mathrm{~km}$ away from Kolkata. It is one of the major thermal power stations in West Bengal. This power plant has 6 units of $210 \mathrm{MW}$ each for a total capacity of $1260 \mathrm{MW}$. The units were commissioned in two stages during the period of 1984 to 1995 . Coal is primary fuel of this power plant.

Village which was located within $5 \mathrm{~km}$ from the power station was investigated as the experimentvillage. Control- village was similar to experiment-village as far as climate, culture and life style concerned and it was located more than $25 \mathrm{~km}$ away from power station.

Subjects:The present study was conducted among school children aged 6-9 years of both sexes studying in Primary schools of above mention villages. The prior written permission of the school authority was taken. Written consent from the parents of the students experimented in the study was obtained. This study was carried out on 186 control subject ( 92 boys and 94 girls) and 159 experimental subjects (76 boys and 83 girls). The students who did not complete the lung function test correctly, who had allergic diseases and who had been hospitalized with respiratory or cardio vascular complaint were excluded.

Spirometry:Spirometry was done using portable computerized spirometer (MedikroSpirostar USB Spirometer, Model: M929, Finland) following the method of Pramanik, 2015 (16) . The complete procedure was explained and demonstrated. All doubts if any were cleared. The subjects were instructed to take a full breath in, close the lips around the mouth piece and blow out as hard and fast possible in standing upright posture. Inspiration should be full and unhurried and expiration once begins should be continued without a pause. Three consecutive spirometric measurements were carried out. The highest values were recorded. Following spirometric parameters were recorded:

Forced vital capacity $(F V C)$ or force expiratory vital capacity): It is the volume of air that can be maximally forcefully exhaled.

Force inspiratory vital capacity $(F I V C)$ : It is the volume of air that can be maximally forcefully inhaled.

Forced expiratory volume in $1^{\text {st }}$ second (FEV1): It is the volume of air that is forcefully exhaled in one second.Forced inspiratory volume in $1^{\text {st }}$ second (FIV1): It is the volume of air that is forcefully inhaled in one second.Peak expiratory flow rate (PEFR): It is the maximum velocity with which air is forced out. It is expressed as liter/sec.

Peak inspiratory flow rate (PIFR): It is the maximum velocity with which air is forced in. It is expressed as liter/sec.

Forced expiratory flow between $25 \%$ and $75 \%$ (FEV25-75\%): It is the flow rate (Liter/sec) over the middle of FVC.

FEF50: It is the flow rate (Liter/sec) over the middle of FVC.

FIF50: It is the flow rate (Liter/sec) over the middle of FIVC.

Mid VC ratio: It is the ratio of FEF50 and FIF50.

The fall in FEV1, PEFR and other flow rates indicate obstructive lung changes (17). FEF25-75\% provides a more sensitive way to assess the early detection and severity of asthma (18). Ratio of EFF50 and FIF50 was used to detect upper airway obstruction (19).

Anthropomeric measurements:Body weight was measured using bathroom scale accurate to $0.5 \mathrm{~kg}$. Weight was taken in light cloth and bare feet. Weight was recorded to the nearest $0.5 \mathrm{~kg}$.

Height was measured using anthropometric rod. Height of the subject was recorded without footwear and expressed to the nearest $0.1 \mathrm{~cm}$. 
BMI was calculated from the height and weight. BMI $\left(\mathrm{kg} / \mathrm{m}^{2}\right)=$ weight $(\mathrm{kg}) /$ height $^{2}(\mathrm{~m})$.

Statistical analysis: Data obtained from the study were given as mean $\pm \mathrm{SD}$. The statistical significance was determined by student's $t$ test. Two tailed $p$ values were used throughout and $p$ value less than 0.05 were judged as statistically significant

\section{Results}

This study was conducted on 168 boys and 177 girls. Age wise distribution of subjects in control and experimental group was represented in table-1.

Table-1: Age wise distribution of study subjects

\begin{tabular}{|l|l|l|l|l|l|l|}
\hline \multirow{2}{*}{ Age (year) } & Boys & Girls & Total & \\
\cline { 2 - 7 } & Control & Experimental & Control & Experimental & Control & Experimental \\
\hline 6 & 18 & 18 & 20 & 17 & 38 & 35 \\
\hline 7 & 24 & 21 & 30 & 21 & 54 & 42 \\
\hline 8 & 26 & 19 & 20 & 21 & 46 & 40 \\
\hline 9 & 24 & 18 & 24 & 24 & 48 & 42 \\
\hline Total & 92 & 76 & 94 & 83 & 186 & 159 \\
\hline
\end{tabular}

Physical characteristic of control and experimental subjects was given in table-2. There were no significant difference of physical parameters between control and respective experimental group of subjects on the basis of sex.

Table-2: Comparison of physical characteristic of study subjects

\begin{tabular}{|c|c|c|c|c|c|c|c|}
\hline \multirow[t]{2}{*}{ Age(year) } & \multirow{2}{*}{$\begin{array}{l}\text { Characteristi } \\
\text { c }\end{array}$} & \multicolumn{3}{|l|}{ Boys } & \multicolumn{3}{|l|}{ Girls } \\
\hline & & Control & Experimental & $\mathrm{p}$ & Control & Experimental & $\mathrm{p}$ \\
\hline \multirow[t]{3}{*}{6} & Height $(\mathrm{cm})$ & $115.50 \pm 6.42$ & $115.20 \pm 3.56$ & $>0.05$ & $115.20 \pm 5.89$ & $114.20 \pm 4.56$ & $>0.05$ \\
\hline & Weight (kg) & $19.66 \pm 5.61$ & $17.70 \pm 0.97$ & $>0.05$ & $17.62 \pm 3.42$ & $17.70 \pm 0.97$ & $>0.05$ \\
\hline & BMI $\left(\mathrm{kg} / \mathrm{m}^{2}\right)$ & $14.63 \pm 3.71$ & $13.06 \pm 0.58$ & $>0.05$ & $13.18 \pm 1.87$ & $13.36 \pm 1.62$ & $>0.05$ \\
\hline \multirow[t]{3}{*}{7} & Height $(\mathrm{cm})$ & $122.08 \pm 5.08$ & $119.25 \pm 4.52$ & $>0.05$ & $118.90 \pm 5.28$ & $117.75 \pm 3.09$ & $>0.05$ \\
\hline & Weight (kg) & $22.10 \pm 5.79$ & $20.00 \pm 3.35$ & $>0.05$ & $19.37 \pm 3.82$ & $18.50 \pm 2.71$ & $>0.05$ \\
\hline & BMI $\left(\mathrm{kg} / \mathrm{m}^{2}\right)$ & $14.68 \pm 2.75$ & $14.03 \pm 1.57$ & $>0.05$ & $13.65 \pm 1.51$ & $13.30 \pm 1.17$ & $>0.05$ \\
\hline \multirow[t]{3}{*}{8} & Height $(\mathrm{cm})$ & $126.55 \pm 5.74$ & $123.70 \pm 6.54$ & $>0.05$ & $125.80 \pm 7.79$ & $124.70 \pm 5.56$ & $>0.05$ \\
\hline & Weight (kg) & $24.85 \pm 6.61$ & $22.00 \pm 3.10$ & $>0.05$ & $22.22 \pm 5.10$ & $22.00 \pm 3.10$ & $>0.05$ \\
\hline & BMI $\left(\mathrm{kg} / \mathrm{m}^{2}\right)$ & $15.39 \pm 3.49$ & $14.16 \pm 1.15$ & $>0.05$ & $13.95 \pm 2.42$ & $14.11 \pm 2.78$ & $>0.05$ \\
\hline \multirow[t]{3}{*}{9} & Height $(\mathrm{cm})$ & $129.30 \pm 7.98$ & $127.50 \pm 4.85$ & $>0.05$ & $129.50 \pm 5.29$ & $127.50 \pm 4.85$ & $>0.05$ \\
\hline & Weight (kg) & $25.09 \pm 4.86$ & $23.80 \pm 3.16$ & $>0.05$ & $25.87 \pm 4.38$ & $23.80 \pm 3.16$ & $>0.05$ \\
\hline & BMI $\left(\mathrm{kg} / \mathrm{m}^{2}\right)$ & $15.42 \pm 1.73$ & $14.53 \pm 1.09$ & $>0.05$ & $15.42 \pm 2.53$ & $14.53 \pm 1.09$ & $>0.05$ \\
\hline
\end{tabular}

*data represent mean $+\mathrm{SD}$

Pulmonary function indices of control and experimental group of children were represented in table-2 to table-8. All the indices were significantly lower in experimental group of children than control counterpart. Decrease of inspiratory function indices was more significant than expiratory function indices.

Table-3: Age wise comparison of FVC (liter) between control and experimental group of children

\begin{tabular}{|l|l|l|l|l|l|l|}
\hline \multirow{2}{*}{ Age (years) } & \multicolumn{3}{|c|}{ Boys } & \multicolumn{3}{c|}{ Girls } \\
\cline { 2 - 7 } & Control & Experimental & \% change & Control & Experimental & $\%$ change \\
\hline 6 & 0.930 & 0.800 & $(-) 14.44$ & 0.795 & 0.690 & $(-) 13.21$ \\
\hline 7 & 1.096 & 0.890 & $(-) 18.79$ & 0.981 & 0.798 & $(-) 18.65$ \\
\hline 8 & 1.118 & 0.955 & $(-) 14.58$ & 1.100 & 0.960 & $(-) 12.73$ \\
\hline 9 & 1.262 & 1.095 & $(-) 13.23$ & 1.184 & 1.020 & $(-) 13.85$ \\
\hline
\end{tabular}

*data represent mean, $\mathrm{p}<0.05$ between age specific control and experimental group, (-) represent decrease, $(+)$ represent increase

Table-4: Age wise comparison of FEV1 (liter) between control and experimental group of children

\begin{tabular}{|l|l|l|l|l|l|l|}
\hline \multirow{2}{*}{ Age (years) } & Boys & Girls & \multicolumn{1}{l|}{} \\
\cline { 2 - 7 } & Control & Experimental & \% change & Control & Experimental & $\%$ change \\
\hline 6 & 0.910 & 0.800 & $(-) 12.09$ & 0.752 & 0.662 & $(-) 11.97$ \\
\hline 7 & 1.072 & 0.870 & $(-) 19.13$ & 0.980 & 0.796 & $(-) 18.78$ \\
\hline 8 & 1.100 & 0.950 & $(-) 13.64$ & 1.090 & 0.955 & $(-) 12.39$ \\
\hline 9 & 1.212 & 1.065 & $(-) 12.13$ & 1.162 & 1.020 & $(-) 12.22$ \\
\hline
\end{tabular}

*data represent mean, $\mathrm{p}<0.05$ between age specific control and experimental group, $(-)$ represent decrease, $(+)$ represent increase 
Table-5: Age wise comparison of PEFR (liter) between control and experimental group of children

\begin{tabular}{|l|l|l|l|l|l|l|}
\hline \multirow{2}{*}{$\begin{array}{l}\text { Age } \\
\text { (years) }\end{array}$} & \multicolumn{3}{|c|}{ Boys } & \multicolumn{3}{c|}{ Girls } \\
\cline { 2 - 7 } & Control & Experimental & \% change & Control & Experimental & \% change \\
\hline 6 & 2.402 & 2.101 & $(-) 12.53$ & 2.284 & 2.007 & $(-) 12.13$ \\
\hline 7 & 2.602 & 2.258 & $(-) 13.22$ & 2.351 & 2.060 & $(-) 12.38$ \\
\hline 8 & 3.041 & 2.692 & $(-) 11.48$ & 2.875 & 2.586 & $(-) 10.06$ \\
\hline 9 & 3.468 & 2.978 & $(-) 14.13$ & 3.115 & 2.765 & $(-) 11.69$ \\
\hline
\end{tabular}

*data represent mean, $\mathrm{p}<0.05$ between age specific control and experimental group (-) represent decrease, $(+)$ represent increase

Table-6: Age wise comparison ofFEF25-75\% (liter) between control and experimental group of children

\begin{tabular}{|l|l|l|l|l|l|l|}
\hline \multirow{2}{*}{$\begin{array}{l}\text { Age } \\
\text { (years) }\end{array}$} & \multicolumn{3}{|c|}{ Boys } & \multicolumn{3}{c|}{ Girls } \\
\cline { 2 - 7 } & Control & Experimental & \% change & Control & Experimental & \% change \\
\hline 6 & 2.036 & 1.726 & $(-) 15.22$ & 1.936 & 1.669 & $(-) 13.80$ \\
\hline 7 & 2.348 & 2.048 & $(-) 14.82$ & 2.010 & 1.768 & $(-) 12.04$ \\
\hline 8 & 2.583 & 2.213 & $(-) 14.32$ & 2.355 & 1.941 & $(-) 17.58$ \\
\hline 9 & 2.685 & 2.300 & $(-) 14.34$ & 2.738 & 2.122 & $(-) 22.50$ \\
\hline
\end{tabular}

*data represent mean, $\mathrm{p}<0.05$ between age specific control and experimental group (-) represent decrease, $(+)$ represent increase

Table-7: Age wise comparison of FIVC (liter) between control and experimental group of children

\begin{tabular}{|l|l|l|l|l|l|l|}
\hline \multirow{2}{*}{$\begin{array}{l}\text { Age } \\
\text { (years) }\end{array}$} & \multicolumn{3}{|c|}{ Boys } & \multicolumn{3}{c|}{ Girls } \\
\cline { 2 - 7 } & Control & Experimental & \% change & Control & Experimental & \% change \\
\hline 6 & 0.919 & 0.700 & $(-) 23.83$ & 0.989 & 0.555 & $(-) 44.00$ \\
\hline 7 & 0.989 & 0.782 & $(-) 20.93$ & 1.001 & 0.597 & $(-) 40.36$ \\
\hline 8 & 1.142 & 0.896 & $(-) 21.54$ & 1.258 & 0.689 & $(-) 30.93$ \\
\hline 9 & 1.396 & 1.142 & $(-) 18.19$ & 1.387 & 0.975 & $(-) 29.70$ \\
\hline
\end{tabular}

*data represent mean, $\mathrm{p}<0.05$ between age specific control and experimental group (-) represent decrease, $(+)$ represent increase

Table-8: Age wise comparison of PIFR (liter/s) between control and experimental group of children

\begin{tabular}{|l|l|l|l|l|l|l|}
\hline \multirow{2}{*}{$\begin{array}{l}\text { Age } \\
\text { (years) }\end{array}$} & \multicolumn{3}{|c|}{ Boys } & \multicolumn{3}{c|}{ Girls } \\
\hline 6 & 1.694 & 1.314 & $(-) 22.43$ & 1.426 & 1.038 & $(-) 27.21$ \\
\hline 7 & 1.782 & 1.404 & $(-) 21.21$ & 1.716 & 1.215 & $(-) 29.20$ \\
\hline 8 & 1.916 & 1.500 & $(-) 23.58$ & 2.169 & 1.616 & $(-) 25.50$ \\
\hline 9 & 2.653 & 1.962 & $(-) 26.04$ & 2.453 & 1.785 & $(-) 27.24$ \\
\hline
\end{tabular}

*data represent mean, $\mathrm{p}<0.05$ between age specific control and experimental group (-) represent decrease, $(+)$ represent increase

Epidemiological studies suggest that children have increased morbidity from particulate air pollution (20). Upper airway deposition of coarse particles are more in children when compare with adults and increased upper airway deposition was correlated with decreasing height of the subjects (21).In order to study upper airway obstruction if any we determined mid vital capacity ratio of study subjects and result was represented in table-9.

Table-9: Age wise comparison of mid vital capacity ratio between control and experimental group of children

\begin{tabular}{|c|c|c|c|c|c|c|}
\hline \multirow{2}{*}{$\begin{array}{l}\text { Age } \\
\text { (years) }\end{array}$} & \multicolumn{3}{|l|}{ Boys } & \multicolumn{3}{|l|}{ Girls } \\
\hline & Control & Experimental & $\%$ change & Control & Experimental & $\%$ change \\
\hline 6 & 1.340 & 1.741 & $(+) 29.90$ & 1.358 & 1.830 & $(+) 34.76$ \\
\hline 7 & 1.263 & 1.684 & $(+) 33.33$ & 1.250 & 1.715 & $(+) 37.20$ \\
\hline 8 & 1.181 & 1.502 & $(+) 27.80$ & 1.216 & 1.550 & $(+) 25.50$ \\
\hline 9 & 1.125 & 1.391 & $(+) 23.64$ & 1.175 & 1.402 & $(+) 19.32$ \\
\hline
\end{tabular}

*data represent mean, $\mathrm{p}<0.05$ between age specific control and experimental group (-) represent decrease, $(+)$ represent increase

\section{Discussion}

Coal-based thermal power plants have been a major source of power generation in India, where $75 \%$ of total power obtained is from coal-based thermal power plants (2). In India ash content in the coal used for power generation is high. Thus liberation of fly ash is also more. India stands on fourth position in the world for the production of coal fly ash as by-product waste. Particulate matter (PM), most important constituent of fly ashmay be deposited into the extra thoracic, tracheobronchial and alveolar regions (3). PM>10um diameter (super coarse particle) is deposited in the extra thoracic region, PM with a diameter between 5 and 10 um 
(coarse particles) is deposited in the tracheobronchial region and particles $<2.5$ um in diameter (fine particles) are deposited in the alveolar region (4).

Breathing zone of children is smaller because of their smaller stature so they inhale air loaded with more particles. Thus children are highly susceptible to airborne pollutants such as those emitted by coal-fired power plants (15). Thus present study investigated the pulmonary function indices of primary school going children living near coal fired thermal power plant.

Epidemiological studies suggest that children have increased morbidity from particulate air pollution $(20,22)$. Upper airway deposition of coarse particles are more in children when compare with adults and increased upper airway deposition was correlated with decreasing height of the subjects (18). Ratio of mid vital capacity was used to determine upper airway obstruction. Ratio above 1.00 indicates variable upper airway obstruction. This ratio was more than 1.00 for both control and experimental children but it was significantly higher for experimental group of children. This result suggests that extra thoracic deposition was more in children living within $5 \mathrm{~km}$ radius of coal fired thermal power plant. Mid vital capacity ratio decreases with increasing age as well as height for both control and experimental children. This observation suggests that extra thoracic deposition correlate with decreasing height. Previous observation of Bennett et al (22) also support this finding.

The finding of this study indicates that, individuals living in village more than $25 \mathrm{~km}$ from power plant were found to be better respiratory health than individuals living within $5 \mathrm{~km}$ of thermal power plant. A study in Mexico reported that even a power plant complying with national standard, their emission can still have significant impact on the health of surrounding population (23). Hon'ble Pope stated that every 10 microgram $/ \mathrm{m}^{3}$ increment in concentration of PM10 in air would result with decrease of $2 \%$ of the pulmonary function (24). In our previous study, the boys of villages located around coal-fired thermal power plant was found to have low FVC, FEV1 and FEF25-75\% (25).

Spirometric findings suggest that living within vicinity of a coal power thermal power plant can result in obstructive lung disease as there is significant reduction of PIFRand PEFR. Extra thoracic deposition of PM is significantly higher in children living with in $5 \mathrm{~km}$ from thermal power plant. Both asthma and COPD involve in obstructing the small airways. FEF $25-75 \%$ is significantly lower $(\mathrm{p}<0.001)$ in children living within $5 \mathrm{~km}$ of thermal power plant than children living more than $25 \mathrm{~km}$ from power plant. FEF $25-75 \%$ is utilized noninvasively to detect airway obstruction in asthma in early stages (26). This finding suggests that children living near coal-fired thermal power plant have every possibility of respiratory obstruction specially asthmaattack at an early age.

\section{Conclusion}

From this study it can be concluded that pulmonary function in school children living within $5 \mathrm{~km}$ of coal-fired thermal power plant is worse than school children living more than $25 \mathrm{~km}$ away from thermal power plant. Obstructive type pulmonary abnormality was noted among children living with in the vicinity of a coal fired thermal power plant. Upper air way and Small air way obstruction was more significant than obstruction of bronchial tree. Earlydiagnosis of small air way non-functioning is important because in mild to moderate asthmatics, treatment during early stage of the disease may be reversible. Thus, Children reside within the locality of coal-fired thermal power plant should undergo regular lung function test to detect respiratory impairment and to minimize major respiratory complication in future by adopting proper precaution.

\section{References}

[1]. IEA 2008. World energy outlook. International Energy Agency. Senapati MR. Fly ash from thermal power plants-waste management and overview. Current Sci. 2011; 100(12): 1791.

[2]. Task Group on Lung Dynamics (TGLD). Deposition and retention models for internal dosimetry of the human respiratory tract. Health Phys. 1966; 12: 173-207.

[3]. Lippmann M, Yeates DB, Albert RE. Deposition, retention and clearance of inhaled particles. Br J Ind Med. 1980; 37: 337-362.

[4]. Dye JA, Adler KB, Richards JD. Role of soluble metals in oil fly ash-induced airway epithelial injury and cytokinegene expression. Am J Physiol. 1999; 277: L498-L510.

[5]. Osornio-Vargas AR, Bonner JC, Alfero-Mereno E et al. Proinflammatory and cytoxic effects of Mexico City air Pollutionparticulatematterin vitro are dependent on particle size and composition. Environ Health Perspect.2003; 111: 1289-1293.

[6]. Sint T, Donohue JF, Ghio AJ. Ambient air pollution particles and the acute exacerbation of chronic obstructive pulmonary disease. InhalToxicol. 2008; 20: 25-29.

[7]. Lagorio S, Forastiere F, Pistelli R et al. Air pollution and lung function among susceptible adult subjects: a panel study. Environ Health. 2006; 5: 11-22.

[8]. Gent JF, Triche GD, Holford TR et al. Association of low-level ozone and fine particles with respiratory symptoms in children with asthma. JAMA. 2003; 290(14): 1859-1867.

[9]. Gauderman WJ, Avol E, Gilliland $\mathrm{F}$ et al. The effect of air pollutants on lung development from 10 to 18 years of age. N Eng J Med. 2004; 351(11): 1057-1067.

[10]. U.S Environmental Protection Agency. Integrated Science Assessment for Particulate Matter. 2009. December-2009; EPA/600/R08/139F. 
[11]. U.S Environmental Protection Agency. Integrated Science Assessment for Oxides of Nitrogen-Health Criteria. 2008. Jully 2008; EPA/600/R-08/071.

[12]. U.S Environmental Protection Agency. Integrated Science Assessment for Sulfur Oxides -Health Criteria. 2008. September 2008; EPA/600/R-08/047F.

[13]. Bateson TF, Schwartz J. Children's response to air pollutants. J Toxicol Environ Health. 2008; 71(3): $238-243$.

[14]. Trasande L, Thurston GD. The role of air pollution in asthma and other pediatric morbidities. J Allergy Clinimmunol. 2005; 115(4): 689-699.

[15]. Pramanik P, Ganguli IN, Ghosh M. Predicted equations of pulmonary function indices for East Indian Adolescent boys aged 10-18 years. IOSR-JDMS. 2015; 14(2): 65-69.

[16]. 17.Rubeena B , Mahagaonkar AM , Kulkarni NB, Nadeem A, Nighute S. Study of pulmonary function tests among smokers and nonsmokers in a rural area. Pravara Med Rev 2009; 4(1): 11-16.

[17]. Tavakol M, GharagozlouM, Afaride M, Movahedi M, Tavakol Z. Asthma diagnosis and treatment-1002. FEF 25-75\%: a more sensitive indicator in the early detection of asthma. World Allergy Organization journal. 2013; 6(suppl 1): p2.

[18]. Karkhanis VS, Joshi JM. Spirometry in chronic obstructive lung disease (COPD). Supplement to JAPI, $2012 ; 60$ : 22-26.

[19]. Dockry DW, Speizer EF, Stram DO, Ware JH, Spengler JD, Ferris BG. Effects of inhalable particles on respiratory health of children. Am Rev Respir Dis. 1989; 139: 587-594.

[20]. Schwartz I, Dockry DW, Neas LM, Wypiz D, Ware JH, Spengler JD, Koutrakis P, Speizer EF, Ferris BG. Acute effects of summer air pollution on respiratory symptoms reporting in children. Am Rev Respir Dis. 1994; 150: 1234-1242.

[21]. Bennett WD, Zeman KL, Kang CW, Schechter MS. Extra thoracic deposition of inhaled coarse particles in children vs adults. Ann OccupHyg. 1997; 41: 497-502.

[22]. Lopez MT, Zuk M, Garibay V et al. Health impacts from power plant emissions in Maxico. Atmos Environ. 2005; 39(1): $199-209$.

[23]. Pope III CA, Bates DV, Raizenne ME. Health effects of particulate air pollution: time for reassessment? Environ Health Perspect. 1995; 103: 472-480.

[24]. Pramanik P, Assault of coal-fired thermal power plant on pulmonary health of school boys aged 7-15 years. IOSR-JDMS. 2015; 14(6): 133-139.

[25]. Zhou Q, Huang GH, Chan CW. Development of an intelligent decision support system for air pollution control at coal-fired powerplants. Expert Sys Appl. 2004; 26: 335-356. 